Beneath the United States 



\title{
Beneath the United States
}

\author{
A HISTORY OF U.S. POLICY \\ TOWARD LATIN AMERICA
}

Lars Schoultz

HARVARD UNIVERSITY PRESS

Cambridge, Massachusetts

London, England 
Copyright $(1998$ by the President and Fellows of Harvard College All rights reserved

Printed in the United States of America

Fourth printing, 2003

Library of Congress Cataloging-in-Publication Data

Schoultz, Lars.

Beneath the United States : a history of U.S. policy toward Latin America / Lars Schoultz.

p. $\mathrm{cm}$.

Includes bibliographical references (p. ) and index.

ISBN 0-674-92275-1 (cloth : alk. paper).

ISBN 0-674-92276-X (pbk. : alk. paper).

1. Latin America-Foreign relations-Latin America.

2. United States-Foreign relations-Latin America.

3. United States-Foreign relations-Moral and ethical aspects.

4. Politicians-United States-Attitudes.

5. United States-Foreign relations-Philosophy.

I. Title.

F1418.S388 1998

327.7308-dc21

97-35338 
To Karina 
